
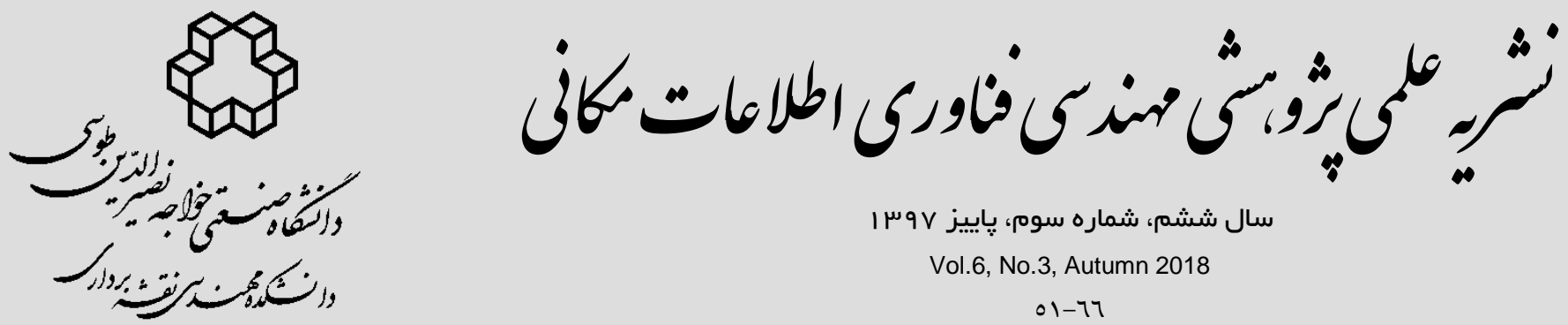

I سال ششم، شماره سوم، ياييز

Vol.6, No.3, Autumn 2018

$01-77$

مدلسازى خطى رطوبت خاك با استفاده از تجزيه و انتخاب ويزَىىهاى تمام قطبيده رادارى

اسماعيل خدرى'، مهدى حسنلو"

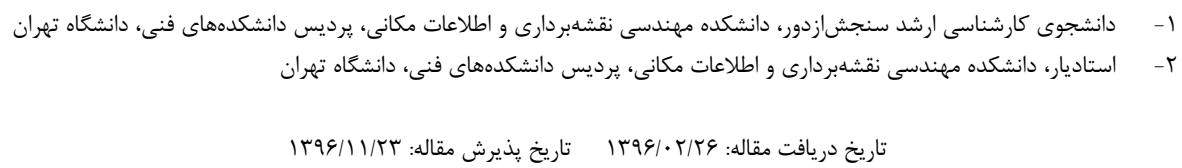

جكيده

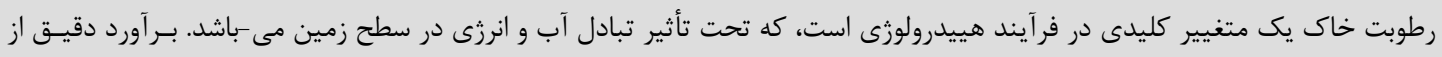

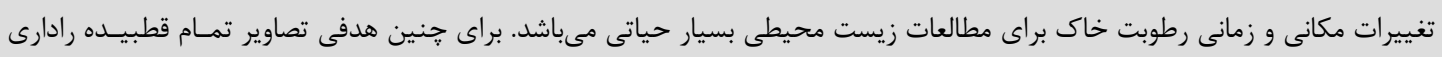

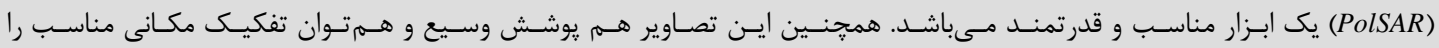

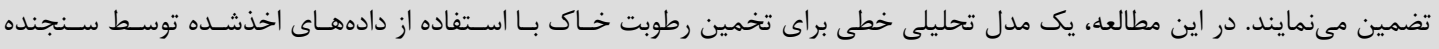

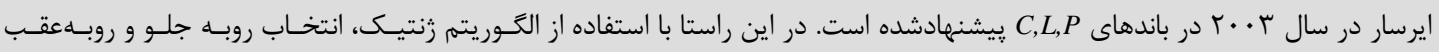

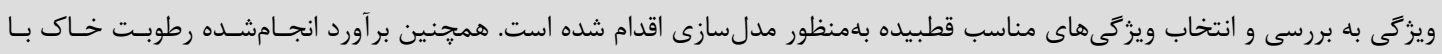

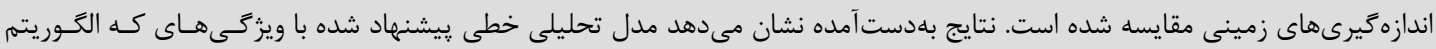

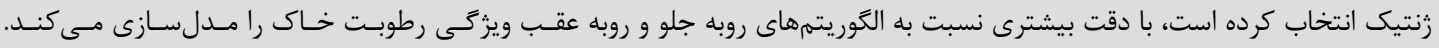

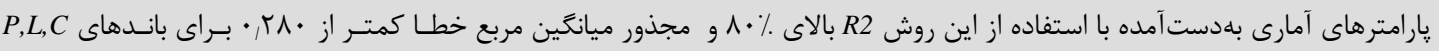

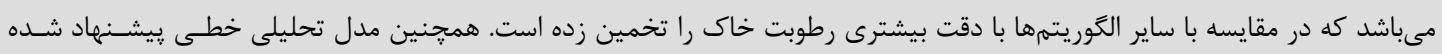

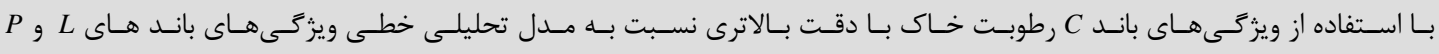
تخمين زده شده است.

كليدوازهها: مدل تحليلى خطى، رطوبت خاك، الكَوريته رُنتيك، الكَوريتهم رو به جلو ، الكَوريته رو به عقب.

"نويسنده مكاتبه كننده: خيابان كاركر شمالى، دانشكده مهندسى نتشهبردارى و اطلاعات مكانى، برديس داشكدهاى فنى، دانشعاه تهران تلفن : 
رابطه بين پارامترهاى سـطح خـاك و سـيخَنال رادار از

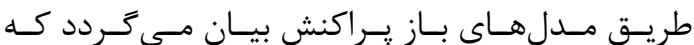

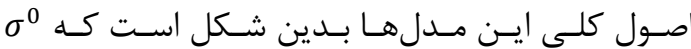

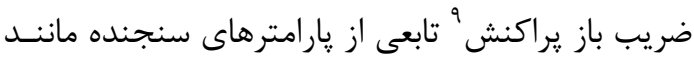

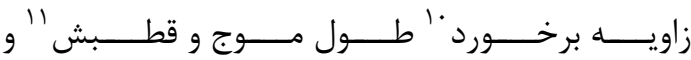
بارامترهاى هدف كه به خصوصيات سطح مانند زبـرى و ورو

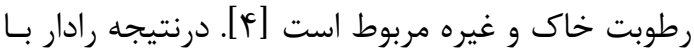
روزنه مجازى و با خصوصـيت تمـام قطبيـده، يتانسـيل

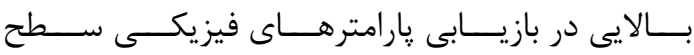

مانند رطوبت و زبرى سطح دارد [ب]. براى محاسبه يارامترهاى سطح مدل هاى بسيارى از بـاز

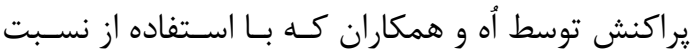
ضرايب باز يراكنش در يلاريزاسيونهاى مختلف رطوبت

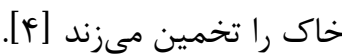

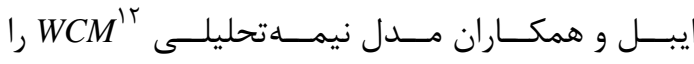

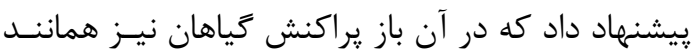

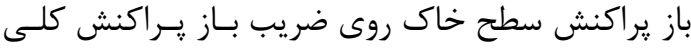

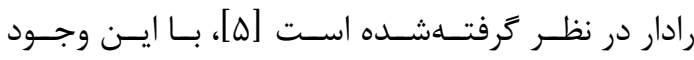
عامل زبرى سطح خاى كه اثرات زيادى بر روى ضـريب

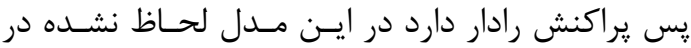
نتيجه مدل WCM تنها براى زمسينهـاى بـا نـاهموارى

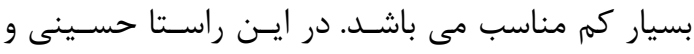

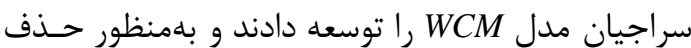
توأم اثر يوشش كياهى و زبرى سطح از روى ضريب بـ بـاز

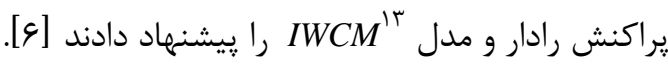

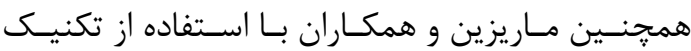
تجزيه קيلاريمتــى دادههـاى "AIRSAR در بانـد Cو رطوبت خاك را با دقت بالاى محاسبه كردهاند. در ايـن تحقيق با فيلتركردن زبرى سطح و تفــاوت قائـل شـدن دردان

\footnotetext{
${ }^{9}$ Backscattering Coefficients

${ }^{10}$ Incident angle

${ }^{11}$ Polarization

${ }^{12}$ Water Cloud Model

${ }^{13}$ Improved Water Cloud Model

${ }^{14}$ Airborne Synthetic aperture radar
}

آب قابل دسترس براى گياهان كه بلهورمعمـول در أر . . . بالاى خاى مىباشد، را رطوبت خاك ' كويند [1]. در مقايسه با مقدار آب موجود در جهان اين لايـهنـازى بــ

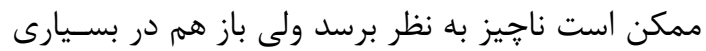

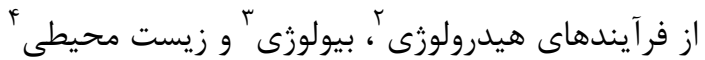

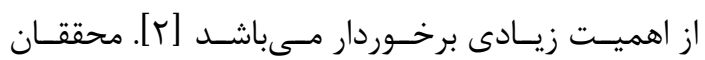

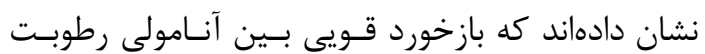
خاك و آبوهوا منطقه مـوردنظر وجــود دارد، درنتيجـهـ تهيه نقشههاى رطوبت خاك با دقت بـالا درك مـا را از آبوهواى منطقه موردنظر بهبود مىبخشد [1] ت. بررسىى

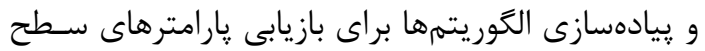

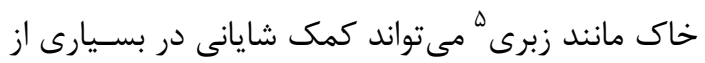

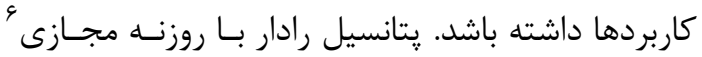

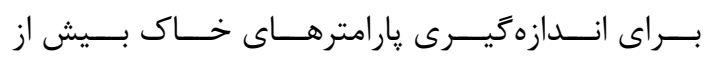

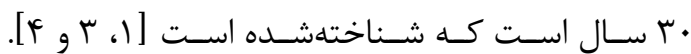
بنابراين ييدا كردن يك راه حـل جديـد بـــاى تخمـين

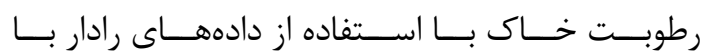

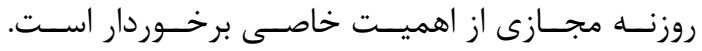
خصوصـيات تصـاوير تمـام قطبيـده رادارى (PolSAR) براى حصول اطمينان هم در يوشش كسترده و همتوان

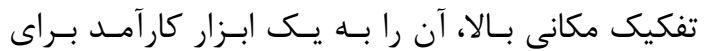
تخمين رطوبت خاى در مقايسه با دادههـاى غيرفعـال

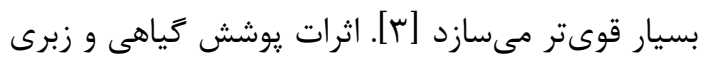

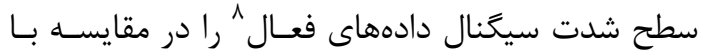
دادههاى غيرفعال تحت تأثير قرار مـى دهـد و از همـين خصوصيت براى تخمين رطوبت خاى استفاده مىشود 
تصاوير استفاده شود. در مطالعهاى حسدادى و همكـاران

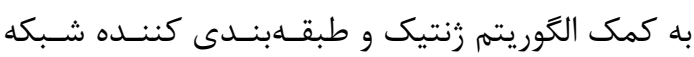

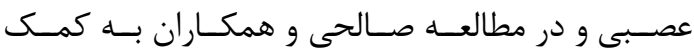

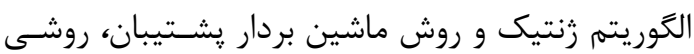

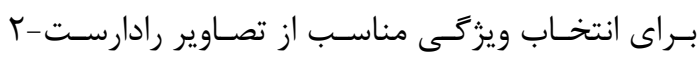

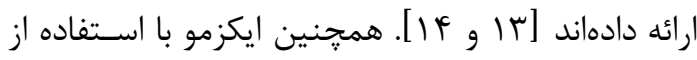

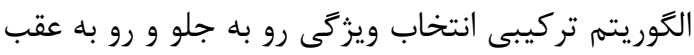

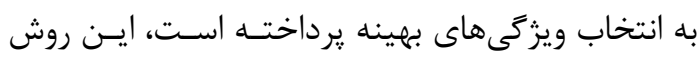

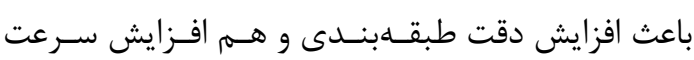

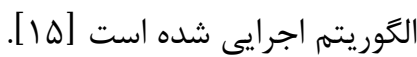

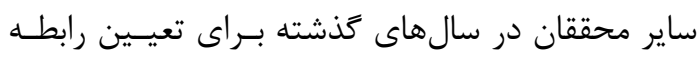

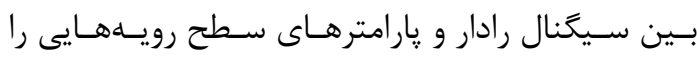

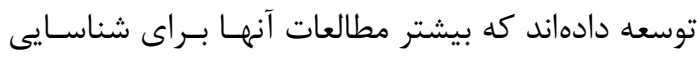

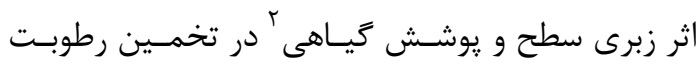
خاك بوده است [ا، أز وه ه].

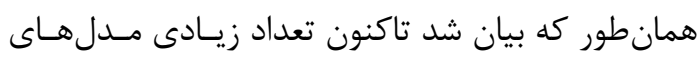

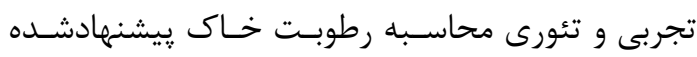

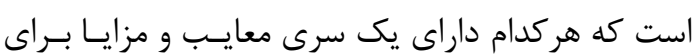

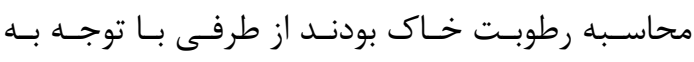

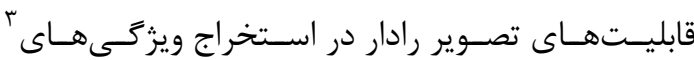
مختلف از مكانيزم سطح زمين ما را بر اين مسى دارد كـهـ

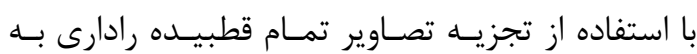
تخمين رطوبت خاك بيردازيم. هدف اين تحقيـق ارائسه

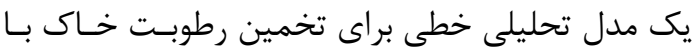

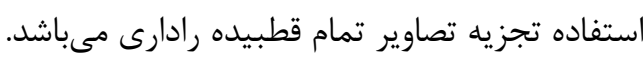

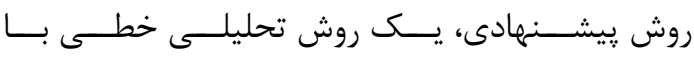

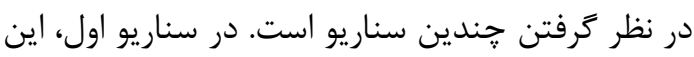

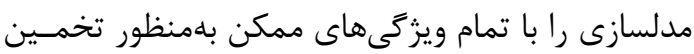

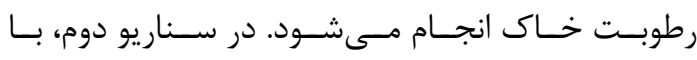

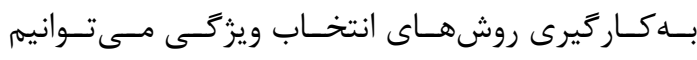

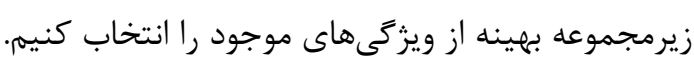

\footnotetext{
${ }^{2}$ Vegetation

${ }^{3}$ Features
}

امضاء طيفى يوشش كَياهى و خاك از روى سطح زمين

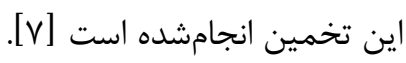

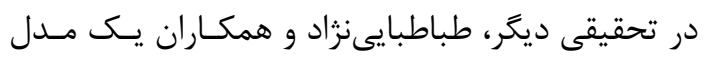
جديد براى تخمين رطوبت خاك با استفاده از دادههاى داى دان

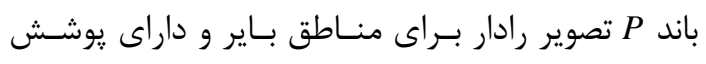

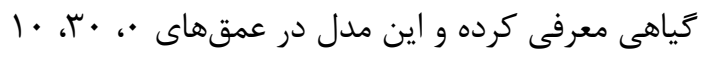

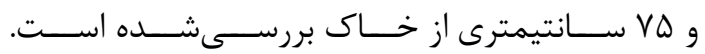

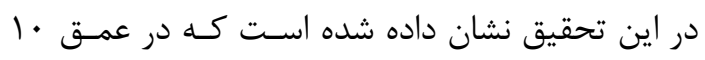

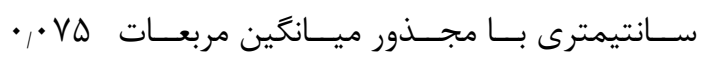
رطوبت خاك با دقت بيشترى نسبت به عمقهاى ديخـر مدلسازى مىشود [1]

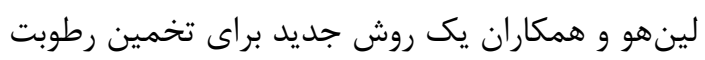

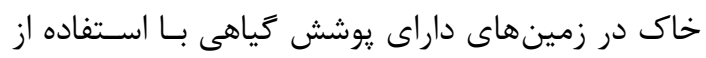

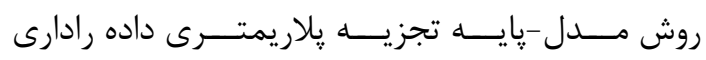

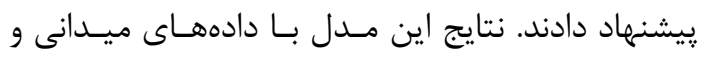

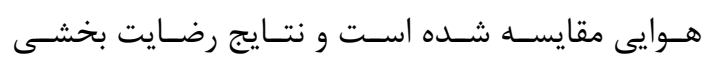
داشته است [ᄉ].

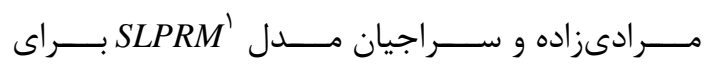

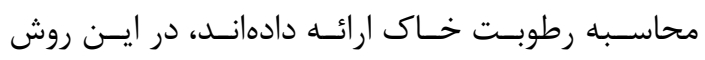

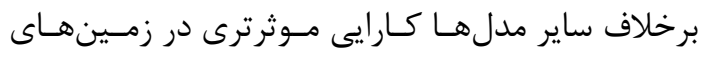

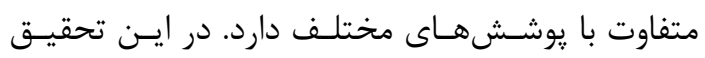
نشان دادهشده است، زمانى كه زبرى سطح باديا استفاده از

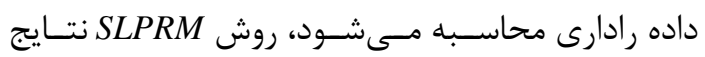

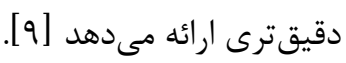

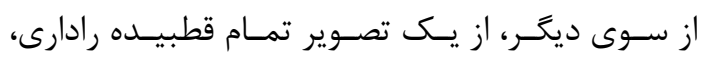
ويزگى هاى قطبيده فراوانى قابل توليد مى دياشد. بنابراين

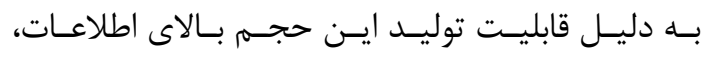

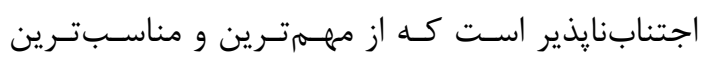

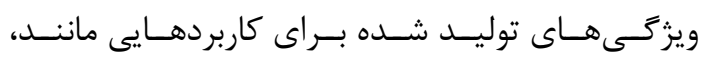
طبقهبندى و مشخص كـردن يارامترهـاى سـطح خـاك

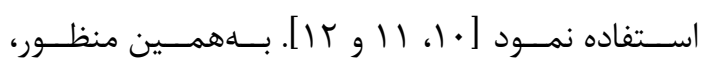

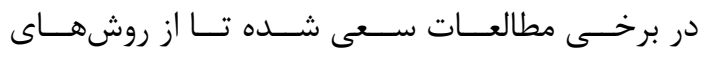

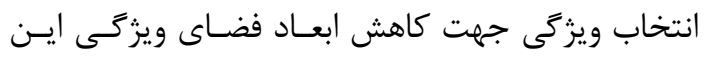

\footnotetext{
${ }^{1}$ Simultaneous Land Parameters Retrieval Model
} 
همــدوس، مــاتريس كواريــانس يــا همدوســى را بـــه

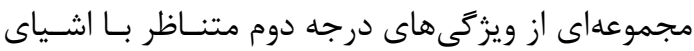

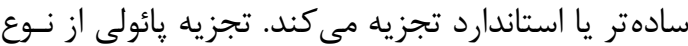

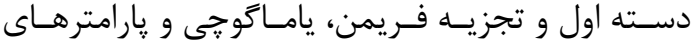

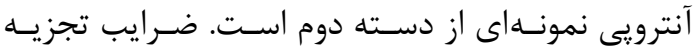

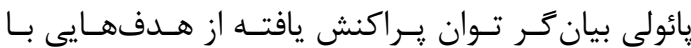

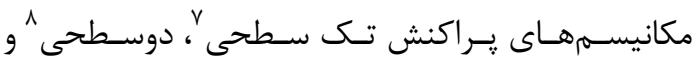

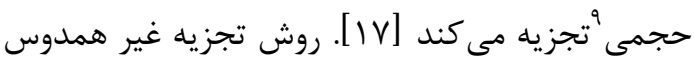

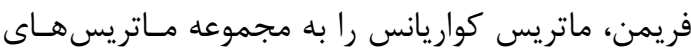

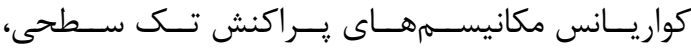

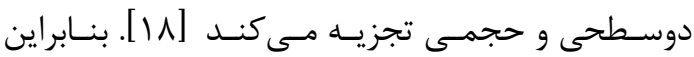

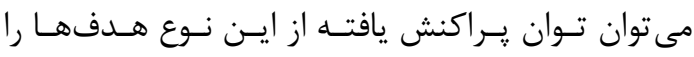

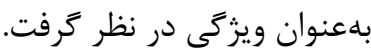

\section{r-Y-Y - روش تخمين خطى}

مدلسازى با استفاده از ويزگگىهاى تصاوير تمام قطبيده رادارى ازجملــه روشهـــاى ســنجشازدورى محاســبه رطوبـت خـاك محسـوب مسىشـود. تـاكنون تحقيقـات

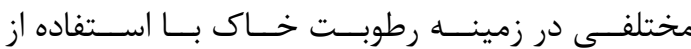

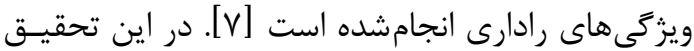
هدف ارائه يك مدل تحليلى خطى براى تخمين رطوبت خاى مطابق رابطه (1) مئباشد.

) رابطه (1)

$S M=1+a_{1} X_{1}+a_{2} X_{2}+\cdots+a_{i} X_{i}+\cdots+$ $a_{m} X_{m}$

در رابطه (1) SM رطوبت خاك برآورد شده، $a_{i}$ ضـرايب

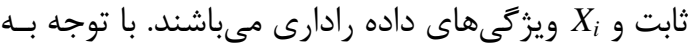

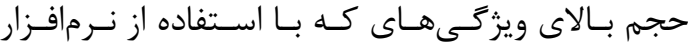
PolSARpro محدود بودن نقاط ميدانى از بـين و9 ويزگتى و تجزيسه

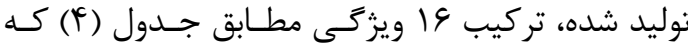

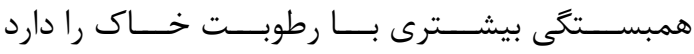

\footnotetext{
${ }^{7}$ Single(Odd)-Bounce

${ }^{8}$ Double(Even)-Bounce

${ }^{9}$ Volume
}

در اين مطالعه ما از الخوريتم 'SGA

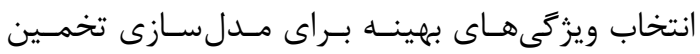

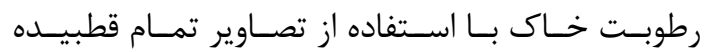
سنجشازدور رادارى استفادهشه است [ع 19]. با در نظر گرفتن موارد مورد بحث، اين يزوهش بـهـ ايـن

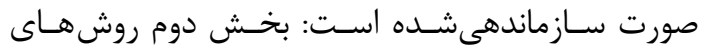
كاربردى استفادهشده را بيان مىنمايد كه شـامل توليـد ويزگَى هاى تجزيه تمام قطبيـده، روش تخمـين خطىى، روش انتخاب ويزگى GA و روش انتخاب ويزگى ترتيبى مىباشد. بخش سوم روش پيشنهادى ارائهشـده

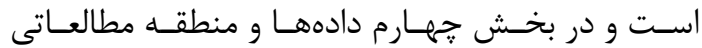
بيانشده است. همجنين در بخش ينجم ييـادهسـازى و

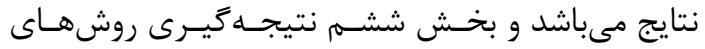

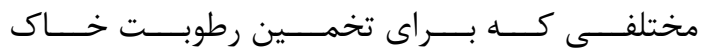
استفادهشه است. r- روشهاى كاربردى استفادهشه مبانى تئورى كه در ايسن تحقيـق اسـتفاده شـده اسـت بdصورت زير مى باشد.

\section{ץ-1- توليد ويزَّى هاى تجزيه تمام قطبيده}

بهطور كلى در اين تحقيق ويزگگى هـــاى قطبيـده كـهـ از تئورىهاى تجزيه هدف به دست مى آيد، استفاده شـده است. ويززَى هاى توليد شده از روشهاى تجزيـه هـدف مى تواند اطلاعات مفيدى درباره مكانيسمهاى يـراكنش

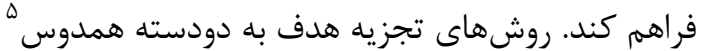

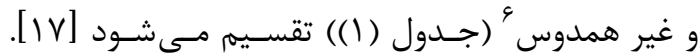
روشهـاى تجزيــه همـدوس، مـاتريس يـراكنش را بــهـ

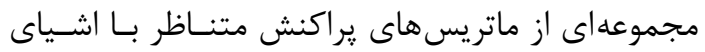

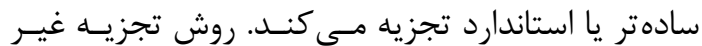

${ }^{1}$ Genetic Algorithm

${ }^{2}$ Sequential Forward Selection

${ }^{3}$ Sequential Backward Selection

${ }^{4}$ Sequential Feature Selector

${ }^{5}$ Coherent

${ }^{6}$ Incoherent 
9ا ويزّكى داده رادارى براى ارائه مـدل تحليلـى خطى

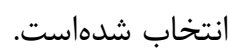

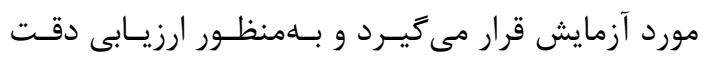

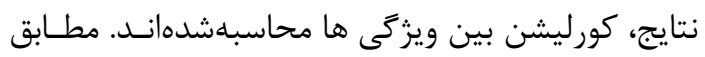

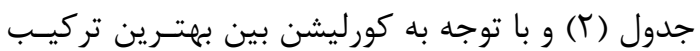

جدول ا: نمونهاى از تجز يههاى همدوس و غير همدوس استفاده شده در اين تحقيق [19].

\begin{tabular}{|c|c|c|c|c|c|c|c|}
\hline |نام تجزيه & ت تعداد & نام تجزيه & ت تعداد & |نام تجزيه & تعداد & |نام تجزيه & |تعداد \\
\hline FRE2-Freeman 2 & r & JRH-Huynen & r & RMB2-Brnes2 & $r$ & WAH1-Holm I & $\mu$ \\
\hline FRE3-Freeman3 & r & KRO-Krogager & r & SRC-Cloude & $\mu$ & WAH2-Holm 2 & $\mu$ \\
\hline HAA-H.A.Alpha & r & NEU-Neuman 2 & r & TSVM-Touzi & 19 & YAM3 Yamaguchi 3 & $\mu$ \\
\hline $\begin{array}{r}\text { HAA-H.A.Alpha- } \\
\text { parameters }\end{array}$ & 11 & RMB1-Brnes1 & r & $\begin{array}{|lr|}V Z 3 & \text { Van } \\
& Z y l(1992) 3 \\
\end{array}$ & $\mu$ & YAM & \\
\hline
\end{tabular}

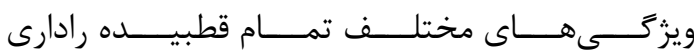

استفاده شده است.

\section{r-r-1- روش انتخاب ويزگى زنتيك}

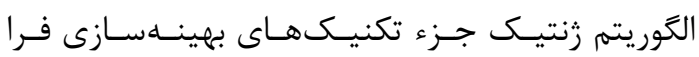

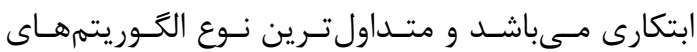

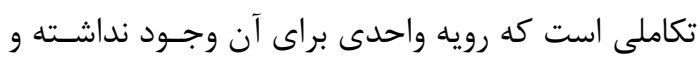

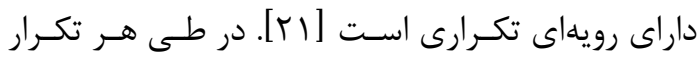
الكوريتم، افراد موجود در جمعيت فعلى بر اساس ميزان

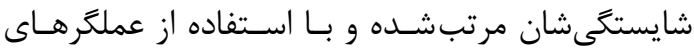

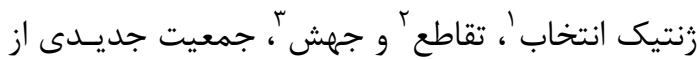

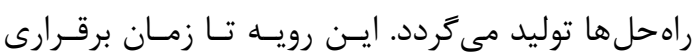

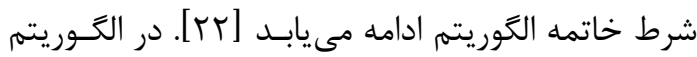
GA هر راه حل توسط يك رشته به نام كروموزوم نمايش

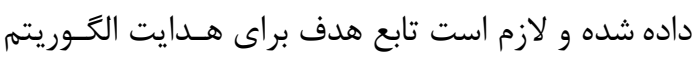

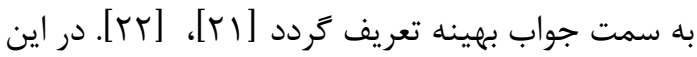
تحقيق از يارامتر آمارى مجذور ميانگَين مربع خطا مدل تحليل خطى جهت تعيين ارزش هر كروموزوم اسـتفاده

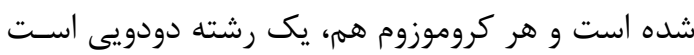

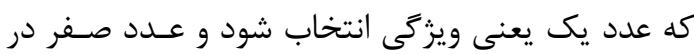
اين كروموزوم يعنى ويزگى مورد نظر انتخاب نشود.

\footnotetext{
${ }^{1}$ Select

${ }^{2}$ Crossover

${ }^{3}$ Mutation
}

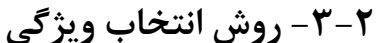

مدل تحليلى يك روش يادگيرى به منظور دستهبنـدى،

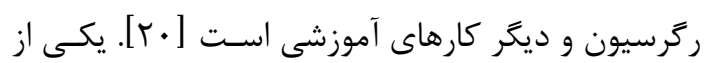

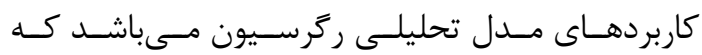

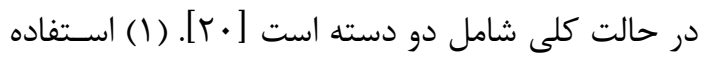

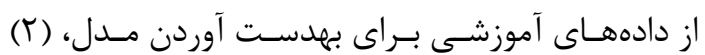

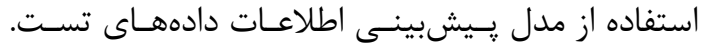

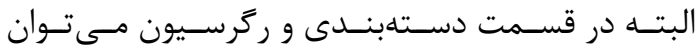

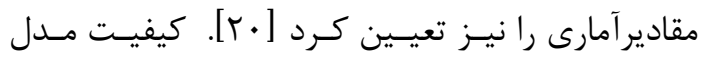

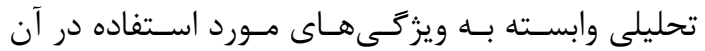

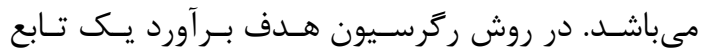
نامعلوم بر مبناى تعداد محدودى از مشاهدات و نمونهها

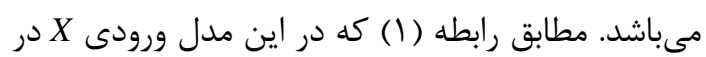

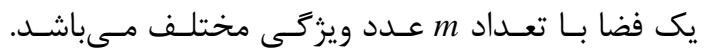

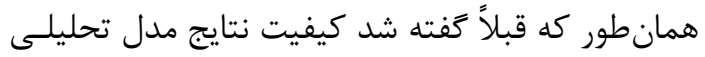

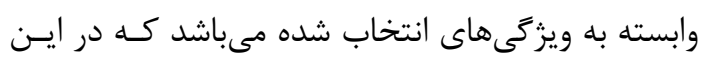

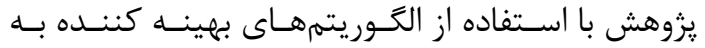

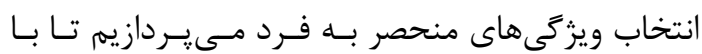

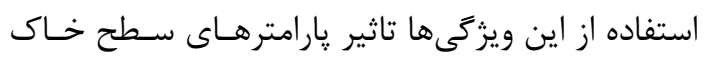
روى ضريب يس يراكنش رادار را بلهنظور ارائه هر جـهـ

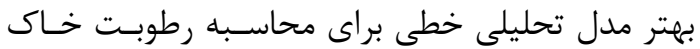

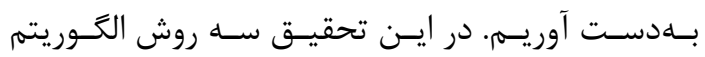

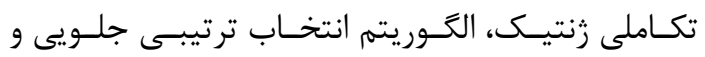

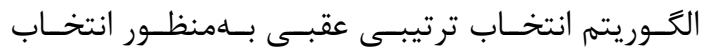


جدول ז: همبستكى بين بهترين تركيب 9 ا ويزگى انتخاب شده

\begin{tabular}{|c|c|c|c|c|c|c|c|c|c|c|c|c|c|c|c|c|}
\hline & $X_{1}$ & $X_{2}$ & $X_{3}$ & $X_{4}$ & $X_{5}$ & $X_{6}$ & $X_{7}$ & $X_{8}$ & $X_{9}$ & $X_{10}$ & $X_{11}$ & $X_{12}$ & $X_{13}$ & $X_{14}$ & $X_{15}$ & $X_{16}$ \\
\hline$X_{1}$ & 1.000 & 0.705 & 0.924 & 0.660 & 0.898 & 0.951 & 0.602 & 0.055 & 0.341 & 0.207 & 0.506 & 0.505 & 0.419 & 0.491 & 0.916 & 0.800 \\
\hline$X_{2}$ & & 1.000 & 0.549 & 0.283 & 0.541 & 0.622 & 0.565 & 0.036 & 0.118 & 0.033 & 0.247 & 0.510 & 0.186 & 0.475 & 0.534 & 0.597 \\
\hline$X_{3}$ & & & 1.000 & 0.547 & 0.790 & 0.806 & 0.702 & 0.159 & 0.445 & 0.001 & 0.322 & 0.603 & 0.231 & 0.616 & 0.999 & 0.880 \\
\hline$X_{4}$ & & & & 1.000 & 0.880 & 0.820 & 0.021 & 0.372 & 0.444 & 0.319 & 0.930 & 0.081 & 0.905 & 0.092 & 0.546 & 0.199 \\
\hline$X_{5}$ & & & & & 1.000 & 0.956 & 0.345 & 0.238 & 0.363 & 0.346 & 0.799 & 0.266 & 0.740 & 0.243 & 0.782 & 0.544 \\
\hline$X_{6}$ & & & & & & 1.000 & 0.347 & 0.278 & 0.347 & 0.372 & 0.729 & 0.246 & 0.657 & 0.224 & 0.798 & 0.610 \\
\hline$X_{7}$ & & & & & & & 1.000 & 0.539 & 0.012 & 0.310 & 0.247 & 0.970 & 0.307 & 0.971 & 0.691 & 0.794 \\
\hline$X_{8}$ & & & & & & & & 1.000 & 0.028 & 0.363 & 0.557 & 0.634 & 0.545 & 0.681 & 0.165 & 0.180 \\
\hline$X_{9}$ & & & & & & & & & 1.000 & 0.157 & 0.244 & 0.008 & 0.217 & 0.035 & 0.459 & 0.207 \\
\hline$X_{10}$ & & & & & & & & & & 1.000 & 0.436 & 0.328 & 0.430 & 0.367 & 0.007 & 0.120 \\
\hline$X_{11}$ & & & & & & & & & & & 1.000 & 0.297 & 0.990 & 0.325 & 0.318 & 0.002 \\
\hline$X_{12}$ & & & & & & & & & & & & 1.000 & 0.348 & 0.987 & 0.588 & 0.684 \\
\hline$X_{13}$ & & & & & & & & & & & & & 1.000 & 0.371 & 0.230 & 0.111 \\
\hline$X_{14}$ & & & & & & & & & & & & & & 1.000 & 0.609 & 0.694 \\
\hline$X_{15}$ & & & & & & & & & & & & & & & 1.000 & 0.876 \\
\hline$X_{16}$ & & & & & & & & & & & & & & & & 1.000 \\
\hline
\end{tabular}

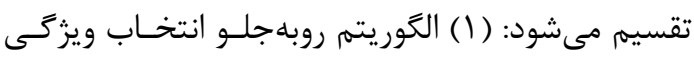

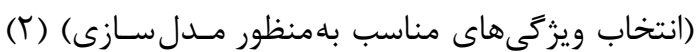

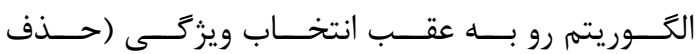
ويزخى هاى زائد بامنظور مدلسازى) [سب]. r- روش يیيشنهادى مدلسازى با استفاده از ويزگىىهاى تصاوير تمام قطبيده

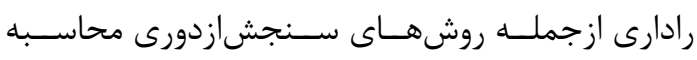
رطوبـت خـاك محسـوب مسىشـود. تـاكنون تحقيقـات مختلفى درزمينه رطوبت خاى با استفاده از ويزگى هاى

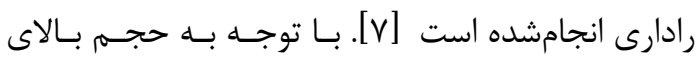

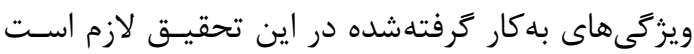

r-r-r-r- روش انتخاب ويزگى ترتيبى الغوريتم SFS يك الخوريته جستجوى حريصـانه است كه بهمنظور كاهش فضايى ويزگى d بعدى اوليه به يـك

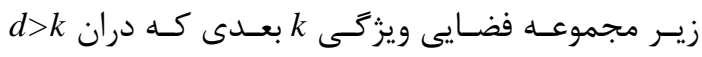

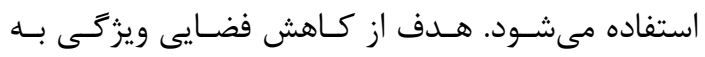

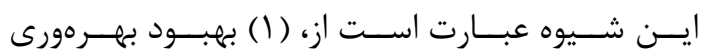
محاسباتى (Y) كاهش خطاى تعميم مـدل هـا بـهـ روش

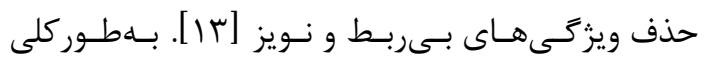

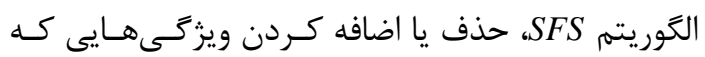
عملكرد آن روى مدل نهايى تأثير دارد را مى گويند. اين عمليات تا زمانى كه يكى زيرمجموعـه ويزگى بهدست بيايد، ادامه مىيابد. الگوريتم SFS به دو دسـته 


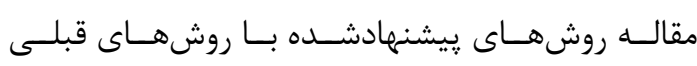
بررسى شده در مطالعات يِيشين هم مقايسه شده اسـت.

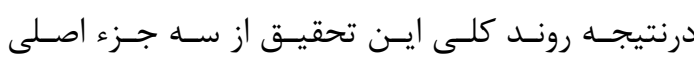
تشكيلشده است () توليد ويزَى هـا از داده AIRSAR،

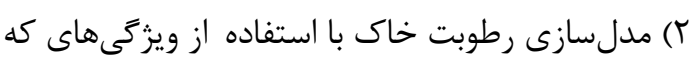

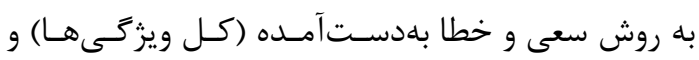

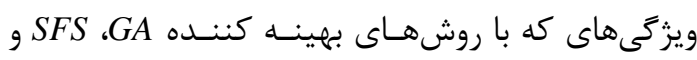
SBS

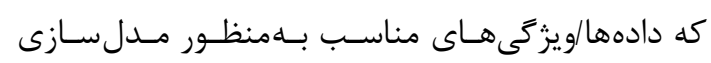



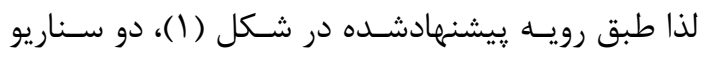

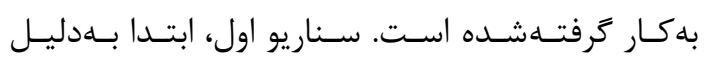
محدوديت موجـود در تعـداد نقــاط ميـدانى از بــين 99

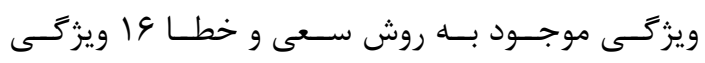
انتخاب و رطوبت خاك را مدل سازى مى كنـيهم. ســاريو

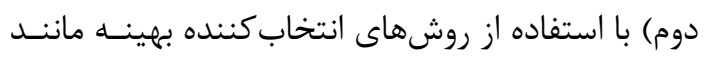

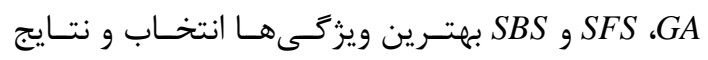

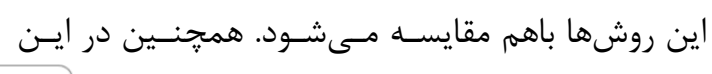
IRSAR $\downarrow$

اعمال تجزيه هاى تمام قطبيده مختلف و استخراج

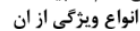

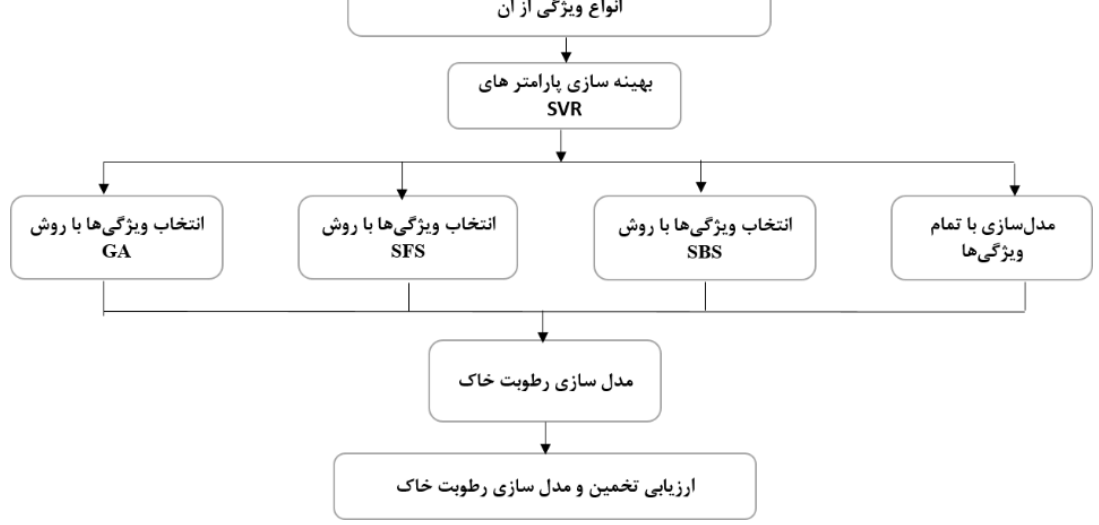

شكل ا: روند كلى مدلسازى رطوبت خاى
F - منطقه مورد مطالعه

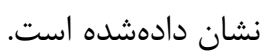

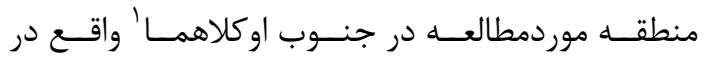

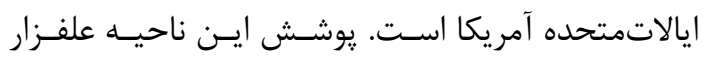

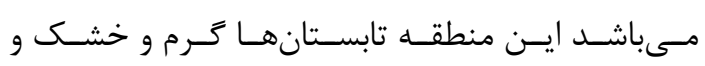

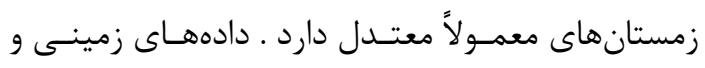

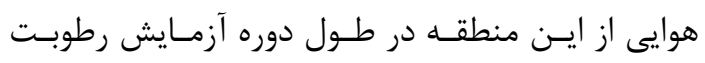

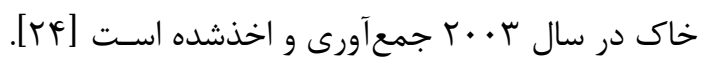

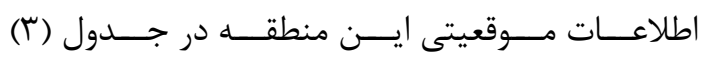
ارائهشده است و همجنين شكل (ץ-الف)، كه برَّرفته از

${ }^{1}$ Oklahoma 
جدول ب: اطلاعات از منطقه موردمطالعه

\begin{tabular}{|c|c|c|c|c|}
\hline منطقه موردمططالعه & \multicolumn{2}{|c|}{ موقعيت } & وضعيت آبوهوا & يوشش گياهى \\
\hline \multirow{2}{*}{ اوكلاهما جنوبى } & بالا سمت راست & $\begin{array}{r}35.0239 \mathrm{~N} \\
98.385 \mathrm{~W} \\
\end{array}$ & \multirow{2}{*}{ نيمه مرطوب } & \multirow{2}{*}{ علفزار } \\
\hline & پايين سمت جٍِ & $\begin{array}{c}34.8693 \mathrm{~N} \\
97.7197 \mathrm{~W}\end{array}$ & & \\
\hline
\end{tabular}

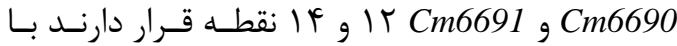

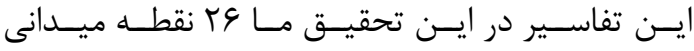

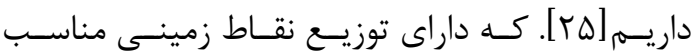
مطـابق شـكل (r-ب) مسىباشــــ اطلاعـات موجــود در هر ييكسل داده AIRSAR نشـاندهنــده يسـ يــراكنش

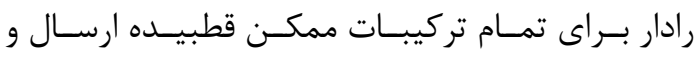
دريسـافتى عمــودى و افقــى (VV,

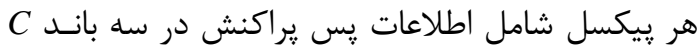

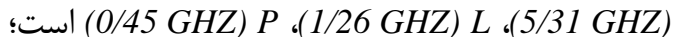

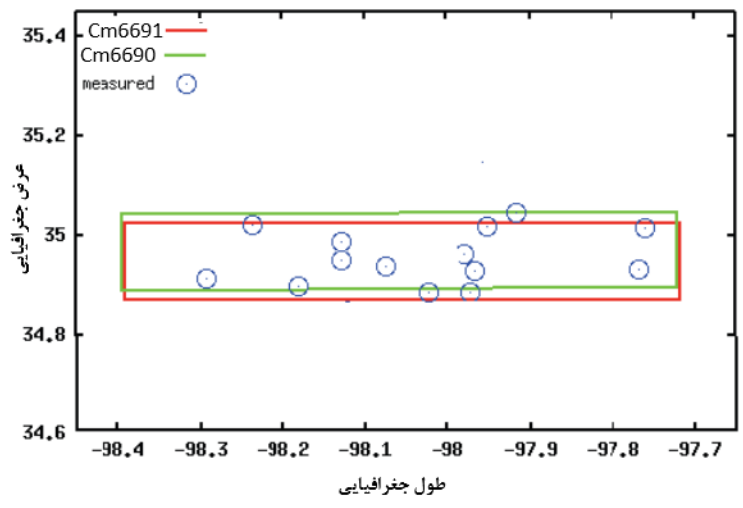

(ب)

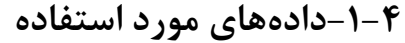

بـهمنظــور اسـتفاده از دادههــاى ميـدانى از دادههــاى SMEX03

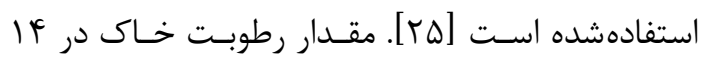

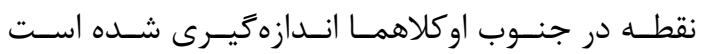
بلهدليـل محسـدود بـودن نقــاط ميـدانى مــا از دو تصـوير

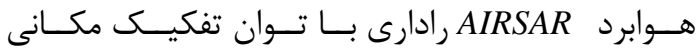
حدود عر4 متر در راستاى برد مايل كه بهطـور همزمـان از اين منطقه استفاده كرديم كـهـ بــهترتيـب در تصـوير

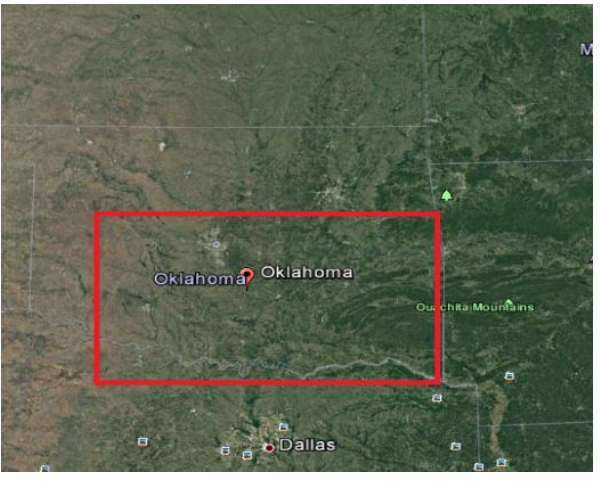

الف)

شكل ז: الف) نماى كلى از منطقه موردمطالعه. تصوير بركرفته از گوكًل ارث. ب) توزيع مكانى نقاط ميدانى بـ

ه-1- روش تخمين رطوبت خاك با تمام ويثزى ها همانطور كه قبلاً كفته شـد در ايسن قسـمت بـهـدليـل محدود بودن نقاط ميدانى براى ارائه يك روش تحليلى خطى براى محاسبه رطوبت خاى به روش سعى و خطا

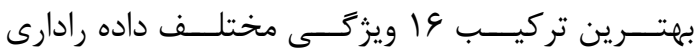

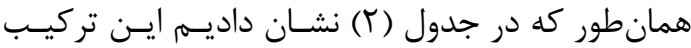
ويزگگى داراى بهترين دقت بـراى مـدل تحليلى خطى

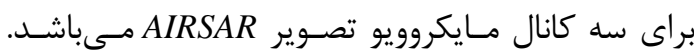
مطابق جدول (Y) انتخابشده است.
ه- ييادهسازى و نتايج نظر به اين كه مـدلسـازى رطوبـت خـاك تحـت تـأثير ويزگ رطوبت خاك را با در نظر گرفتن تأثير تمام ويزگىىهـا،

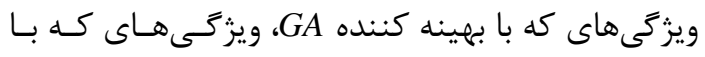
بهينه كننده SFS و ويزگ انتخابشده است، موردبررسى و تحليل قرار مى گيرد. 
جدول F: ويزَكىهاى كه با روش سعى و خطا انتخابشدهاند

\begin{tabular}{|c|c|c|c|}
\hline شماره & نام ويزَى & شماره & نام ويزگى \\
\hline$X_{1}$ & VanZyl3_Odd & $X_{9}$ & Beta \\
\hline$X_{2}$ & Freeman_Vol & $X_{10}$ & combination_1mH1mA \\
\hline$X_{3}$ & Barnes1_T22 & $X_{11}$ & Barnes1_T11 \\
\hline$X_{4}$ & Freeman_Dbl & $X_{12}$ & Barnes1_T33 \\
\hline$X_{5}$ & Holm2_T11 & $X_{13}$ & Barnes2_T11 \\
\hline$X_{6}$ & Yamaguchi3_Odd & $X_{14}$ & Barnes2_T33 \\
\hline$X_{7}$ & HAAlpha_T33 & $X_{15}$ & Barnes2_T22 \\
\hline$X_{8}$ & Anisotropy & $X_{16}$ & Cloude_T33 \\
\hline
\end{tabular}

كانال مـايكروويو تصـوير AIRSAR مطـابق جـدول (ه)

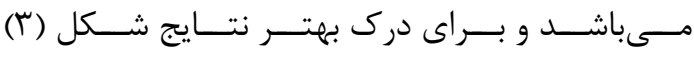
ارائه شده است.
در اين تحقيق، وب نقطه ميـدانى داريسم كـه 11 نقطـه براى آموزش مدل تحليلى خطى و 1 نقطه بـراى تسـت

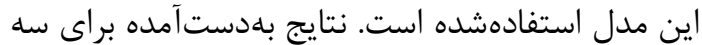

جدول ه: نتايج حاصل از مدل تحليلى خطى با كل ويزگكىها

\begin{tabular}{|r|r|r|r|r|r|r|}
\hline \multirow{2}{*}{ بانyyyy|} & \multicolumn{2}{|c|}{$R^{2}$} & & \multicolumn{2}{r|}{ RMSE } & \multicolumn{1}{|c|}{ SSE } \\
\cline { 2 - 7 } & Test & Train & Test & Train & Test & Train \\
\hline$C$ & 84.73 & 80.12 & 0.0330 & 0.0394 & 0.0087 & 0.012 \\
$L$ & 63.17 & 60.39 & 0.0773 & 0.0912 & 0.0189 & 0.0253 \\
$P$ & 60.59 & 59.17 & 0.0744 & 0.0812 & 0.0335 & 0.0487 \\
\hline
\end{tabular}

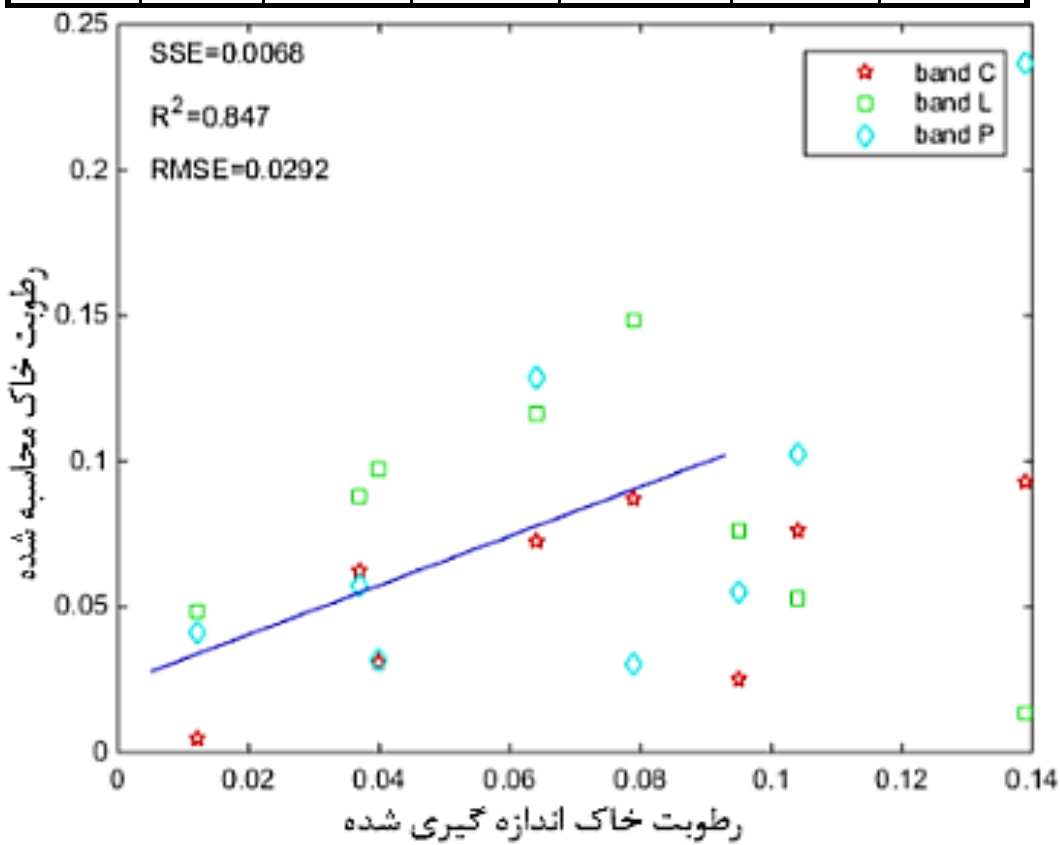

شكل ץ: .مقايسه مقدار اندازهَيرى شده و تخمين زدهشده رطوبت خاك در باند P,L,C با استفاده از كل ويزگى ها.

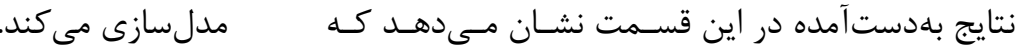

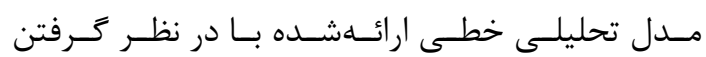

$$
\begin{aligned}
& \text { ويزگَىهاى كانال C تصوير AIRSAR رطوبت خاى را بـا } \\
& \text { دقت بهترى نسبت به كانال هاى L و P }
\end{aligned}
$$


انتخــاب مـى كنـــم. يارامترهــاى GA مورداسـتفاده در

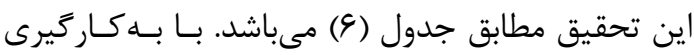

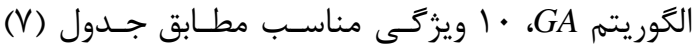
انتخابشده است. و معيار انتخاب جمعيت كمينه كردن مقدار RMSE مىباشد.

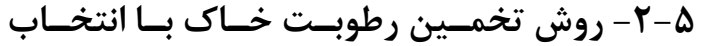
ويزَى هاى بهينه با الگوريته زنتيك در اين قسمت بــا اسـتفاده از الخــوريتم GA از بـين 19 ويزگى كه به روش سعى و خطا بهدست آمدهاند، بهترين

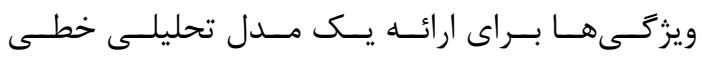

GA جدول \&: يار امترهاى اجراى الكوريتم

\begin{tabular}{|c|c|}
\hline يارامترهاى الگوريتم زنتيك & مقدار يارامترها \\
\hline Population & 20 \\
\hline Elitism & 1 \\
\hline Crossover & 0.7 \\
\hline Mutation & 0.05 \\
\hline Max Iterations & 70 \\
\hline Method Crossover & 2 \\
\hline
\end{tabular}

جدول \: ويثَّى هاى انتخابشده با استفاده از الكوريتم بهينه كننده GA.

\begin{tabular}{|c|c|c|c|}
\hline شماره & نام ويزگى & شماره & نام ويزگ \\
\hline$X_{2}$ & Freeman_Vol & $X_{9}$ & Beta \\
\hline$X_{3}$ & Barnes1_T22 & $X_{11}$ & Barnes1_T11 \\
\hline$X_{5}$ & Holm2_T11 & $X_{14}$ & Barnes2_T33 \\
\hline$X_{6}$ & Yamaguchi3_Odd & $X_{15}$ & Barnes2_T22 \\
\hline$X_{7}$ & HAAlpha_T33 & $X_{16}$ & Cloude_T33 \\
\hline
\end{tabular}

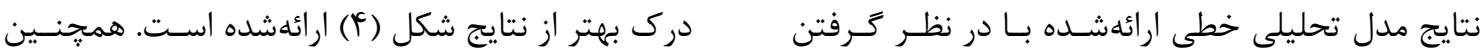

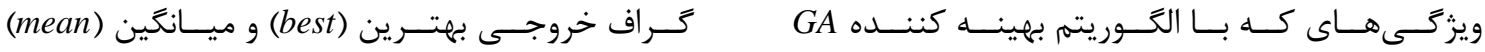

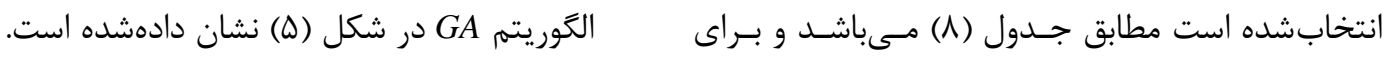

جدول ^. نتايج حاصل از مدل تحليلى خطى با ويزگى هاى انتخابشده به روش GSE.

\begin{tabular}{|r|r|r|r|r|r|r|}
\hline \multirow{2}{*}{ بانyyyy|} & \multicolumn{3}{|c|}{$R^{2}$} & & RMSE & \multicolumn{2}{r|}{ SSE } \\
\cline { 2 - 7 } & Test & Train & Test & Train & Test & Train \\
\hline$C$ & 88.17 & 85.73 & 0.0188 & 0.0263 & 0.0026 & 0.0092 \\
$L$ & 87.29 & 79.13 & 0.0191 & 0.0301 & 0.0054 & 0.0101 \\
$P$ & 83.03 & 55.21 & 0.028 & 0.0397 & 0.0335 & 0.094 \\
\hline
\end{tabular}


بهناز بيكدلى و همكاران

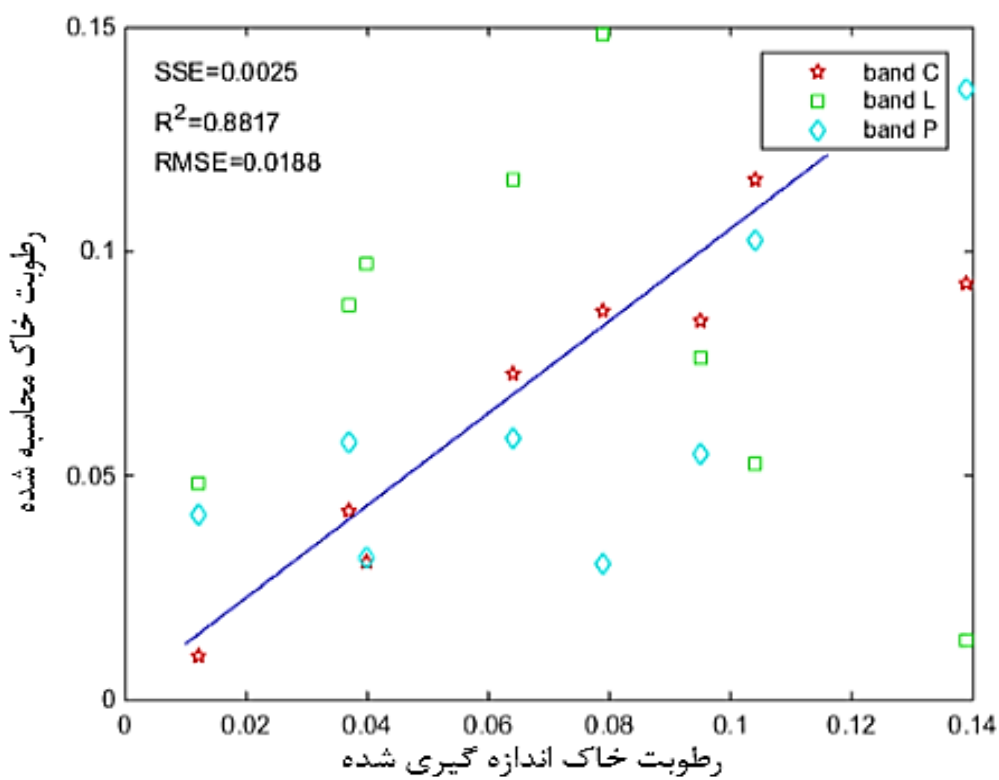

شكل f: مقايسه مقدار اندازهَيرى شده و تخمين زدهشده رطوبت خاك در باند P,L,C با استفاده از ويزَّىهاى انتخابشده با GA.

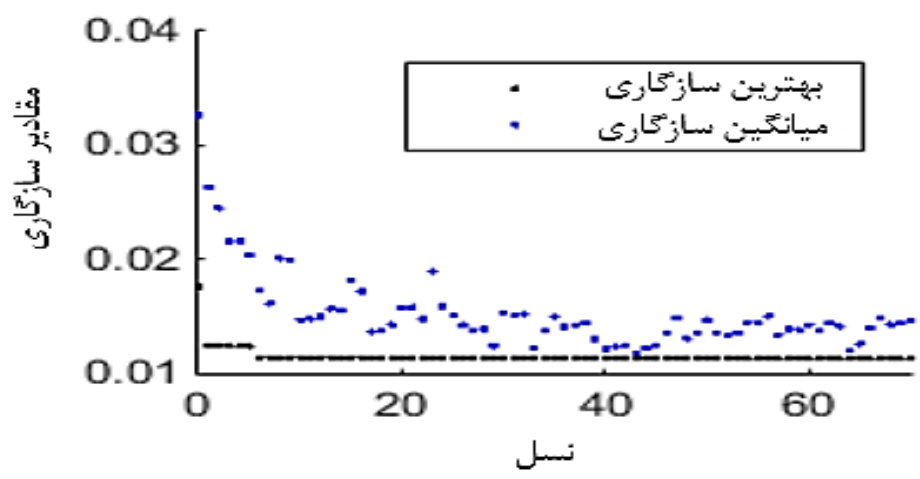

شكل ه: تَراف best و mean براى روند اجراى الكور يتم GA.

انتخاب ويزخى هاى بهينه با الكوريتهم ترتيبى به دو روش

$$
\text { بهورت زير مىباشد: }
$$

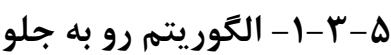

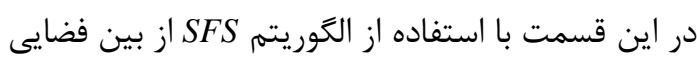

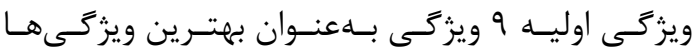

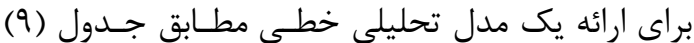
انتخابشده است.
همان كونه كه ملاحظه مىشود رطوبت خـاك بـا دقت

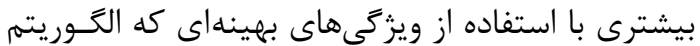
انتخاب كرده است مدلسازى مسىشـود. همجنــين

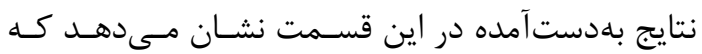

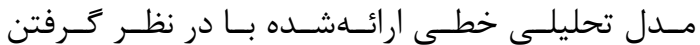

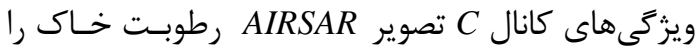
بـا دقـت بهتـرى نسـبت بـهـ كانـال هـاى Lاس و P تصـوير AIRSAR مدل سازى مى كند.

ه-ץ- روش تخمـين رطوبـت خــاك بــا انتخـــاب ويزگى هاى بجينه با الكوريتم ترتيبى بلهور كلى همانطور كه در بخشهـاى قبـل ذكـر شـــ 
جدول 9: ويثزى هاى انتخابشده با استفاده از الكَوريتم بهينه كننده SFS.

\begin{tabular}{|c|c|c|c|}
\hline شماره & نام ويزگى & شماره & نام ويزگ \\
\hline$X_{1}$ & VanZyl3_Odd & $X_{11}$ & Barnes1_T11 \\
\hline$X_{2}$ & Freeman_Vol & $X_{14}$ & Barnes2_T33 \\
\hline$X_{5}$ & Holm2_T11 & $X_{15}$ & Barnes2_T22 \\
\hline$X_{6}$ & Yamaguchi3_Odd & $X_{16}$ & Cloude_T33 \\
\hline$X_{9}$ & Beta & & \\
\hline
\end{tabular}

انتخابشده است. مطابق جدول (• (1) مىباشـد و بـراى نتايج مدل تحليلى خطى ارائهشـده بـا در نظـر خـرفتن

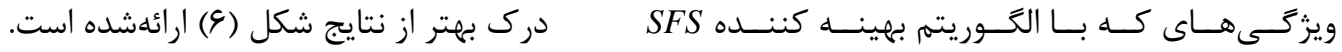

جدول •ا: نتايج حاصل از مدل تحليلى خطى با ويثَّى هاى انتخابشده به روش SFS

\begin{tabular}{|c|c|c|c|c|c|c|}
\hline \multirow{2}{*}{ باند } & \multicolumn{2}{|r|}{$R^{2}$} & \multicolumn{2}{|r|}{$R M S E$} & \multicolumn{2}{|r|}{$S S E$} \\
\hline & Test & Train & Test & Train & Test & Train \\
\hline$C$ & 83.46 & 74.46 & 0.0118 & 0.025 & 0.0013 & 0.0092 \\
\hline$L$ & 79.18 & 47.3 & 0.012 & 0.0413 & 0.0012 & 0.0021 \\
\hline$P$ & 58.78 & 33.39 & 0.023 & 0.0311 & 0.0050 & 0.094 \\
\hline
\end{tabular}

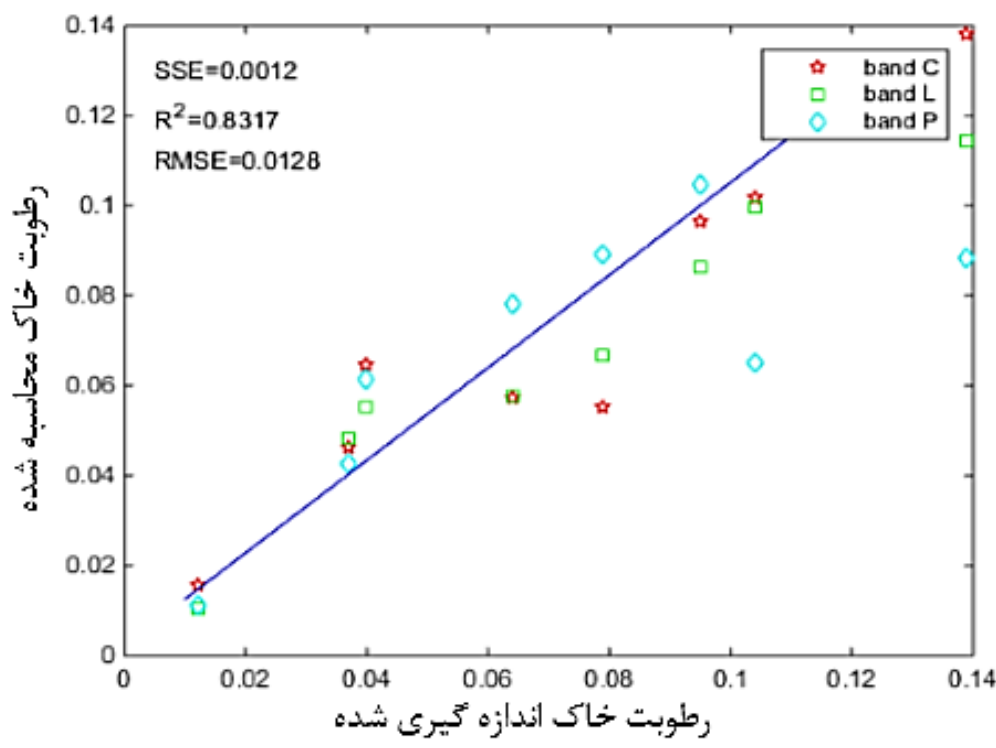

شكل צ: مقايسه مقدار اندازهَيرى شده و تخمين زدهشده رطوبت خاك در باند P,L,C با استفاده از ويثَى هاى انتخابشده با SFS.

$$
\begin{aligned}
& \text { P تصوير AIRSAR مدل سازى مى كند. } \\
& \text { ه-r-r-r- الكَوريتم رو به عقب }
\end{aligned}
$$

با استفاده از الخوريتم SBS از بين فضايى ويزگتى اوليـهـ

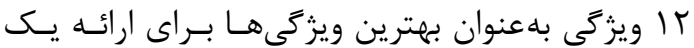

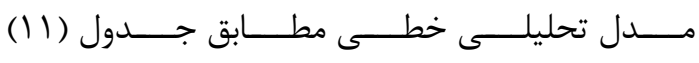
انتخابشده است.
همان ₹ونه كه ملاحظه مىشود رطوبت خاك با اسـتفاده

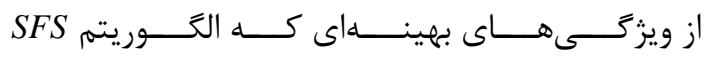
انتخاب كرده است، با دقت پايينترى مدل سـازى شـده

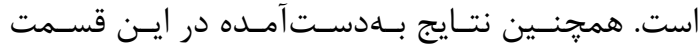

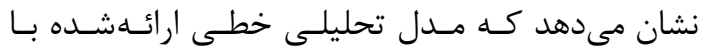
در نظر گرفتن ويزخىىهـاى كانسال C تصـوير AIRSAR رطوبت خاى را با دقت بهترى نسبت به كانالهـاى L و و 
جدول ||: ويزگكىهاى انتخابشده با استفاده از الكَوريتم بهينه كننده SBS.

\begin{tabular}{|c|c|c|c|}
\hline شماره & نام ويز گى & شماره & نام ويزگ \\
\hline$X_{3}$ & Barnes1_T22 & $X_{11}$ & Barnes1_T11 \\
\hline$X_{4}$ & Freeman_Dbl & $X_{12}$ & Barnes1_T33 \\
\hline$X_{6}$ & Yamaguchi3_Odd & $X_{13}$ & Barnes2_T11 \\
\hline$X_{7}$ & HAAlpha_T33 & $X_{14}$ & Barnes2_T33 \\
\hline$X_{8}$ & anisotropy & $X_{15}$ & Barnes2_T22 \\
\hline$X_{9}$ & beta & $X_{16}$ & Cloude_T33 \\
\hline
\end{tabular}

انتخابشده است مطابق جدول (r () مسىباشـد و بـراى درك بهتر از نتايج شكل (V) ارائهشده است.
نتايج مدل تحليلى خطى ارائهشـده بـا در نظـر گــرفتن

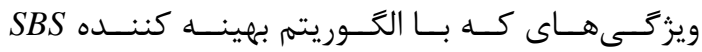

جدول זا: نتايج حاصل از مدل تحليلى خطى با ويثَى هاى انتخابشده

\begin{tabular}{|c|c|c|c|c|c|c|}
\hline \multirow{2}{*}{ باند } & \multicolumn{2}{|r|}{$R^{2}$} & \multicolumn{2}{|r|}{$R M S E$} & \multicolumn{2}{|r|}{$S S E$} \\
\hline & Test & Train & Test & Train & Test & Train \\
\hline $\bar{C}$ & 49.93 & 50.49 & 0.0402 & 0.0328 & 0.0129 & 0.0123 \\
\hline$L$ & 55.82 & 39.25 & 0.0909 & 0.1436 & 0.0661 & 0.0682 \\
\hline$P$ & 56.30 & 33.53 & 0.7109 & 0.6476 & 0.2114 & 0.2129 \\
\hline
\end{tabular}

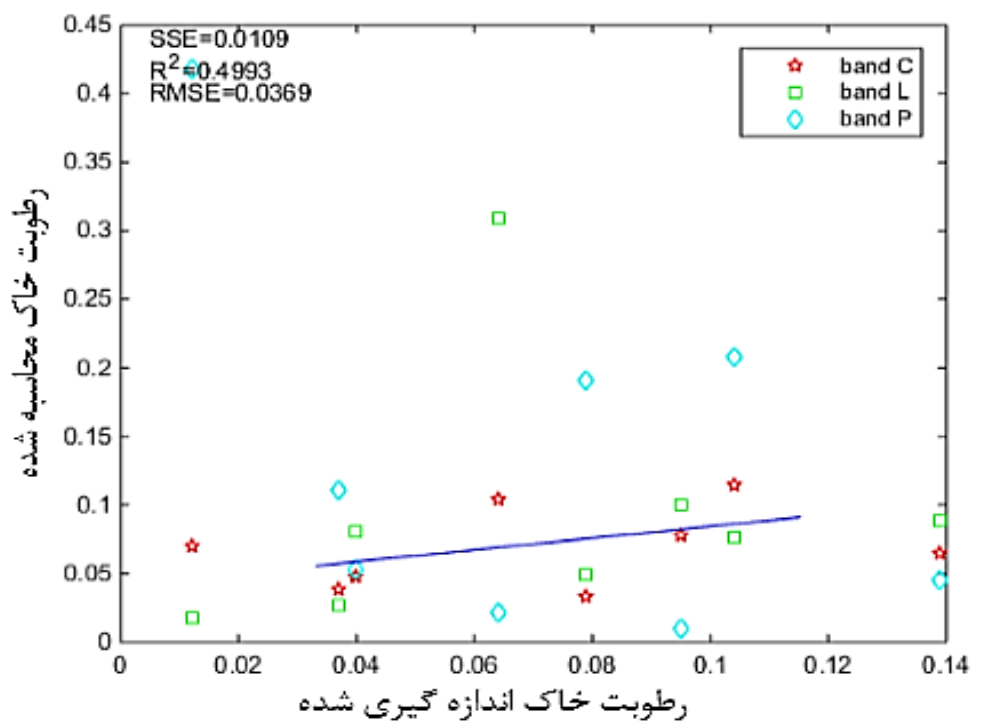

شكل V: مقايسه مقدار اندازهَيرى شده و تخمين زدهشده رطوبت خاك در باند P,L,C با استفاده از ويزَىىهاى انتخابشده با SBS

رطوبت خاى را با دقت بهترى نسبت به كانال هـاى L P تصوير AIRSAR مدل سازى مى كند.

$$
\text { P- }-\mathbf{p}
$$

بdمنظور بررسى اثرات يوشش زياهى و زبرى سـطح بـر

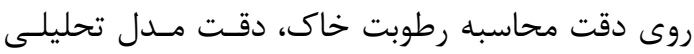

همان گونه كه ملاحظه مىشود رطوبت خاكى با اسـتفاده

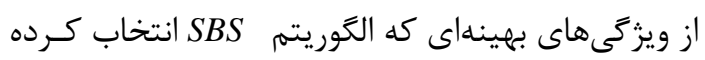
است، با دقت پايين ترى نسبت به تمام روش هاى ديخـر مدل سازى مىشود. همجنين نتايج بهدستآمده در ايـن قسمت نشان مىدهد كه مدل تحليلى خطى ارائه شده با

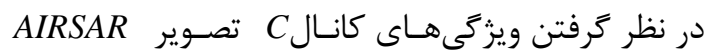


مدل تحليلى خطى با استفاده از ويزگى هاى انتخابشده

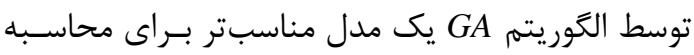

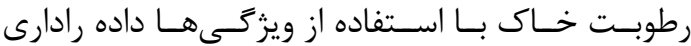
مىباشد.

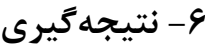

در اين تحقيق سعى شد با توجه به دادههاى موجـود از سه الخوريتم انتخاب ويزگگىهاى بهينه

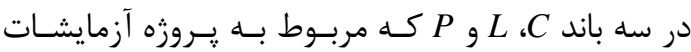

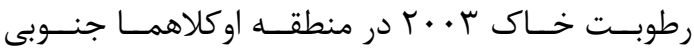

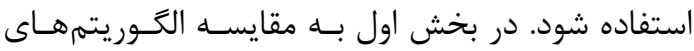

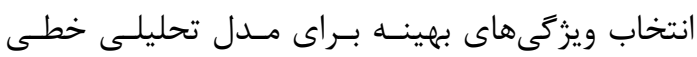

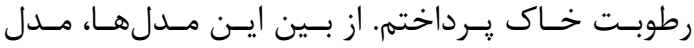

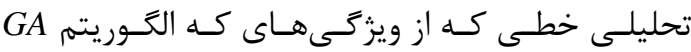

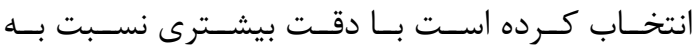
مدل تحليلى خطى با در نظر گرفتن تمـام ويزگَىهـا و

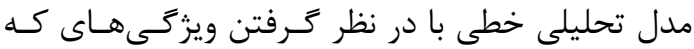

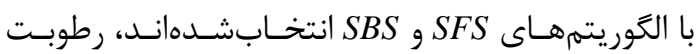
خاى را مدلسازى مى كنــد. در بخــش دوم بـهـ مقايسـهـ مدلهاى مختلـف تخمـين رطوبـت خـاك در بانـدهاى مختلـف مسى يــردازيم. از بـين ســه بانـد داده AIRSAR

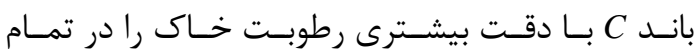
مدلهاى ييادهسازى شده مدلسازى مسى كنـد و بعـد از

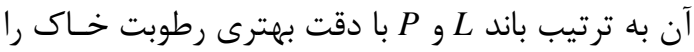
مدلسازى مى كنند. ازجمله نتايج اين تحقيق مسى تـوان

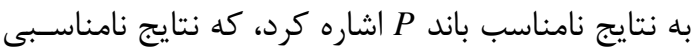
نسبت به ساير باندها دارد. همرجنين نتايج ضـعيفتـرى بـ

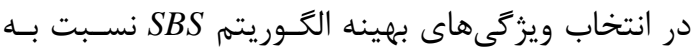

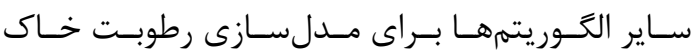

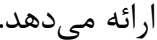

[1] A. Tabatabaeenejad, M. Burgin, X. Duan, and M. Moghaddam, "P-Band Radar Retrieval of Subsurface Soil Moisture Profile as a Second-Order Polynomial: First AirMOSS Results,” IEEE Trans. Geosci.
خطى با استفاده از ويزخَىهـاى داده رادارى در حالـت

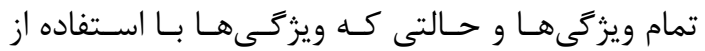

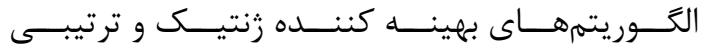

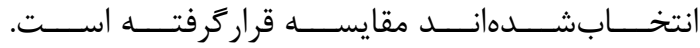

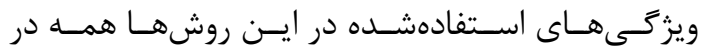

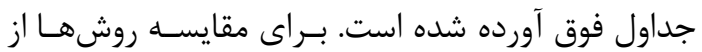

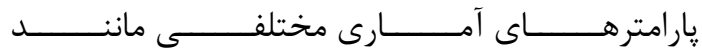
مجذور ميانگين مربع خطا (RMSE)، ضريب همبستگى (RSE) و مجموعه مربعات خطا (SSE) استفاده مسى مـــود.

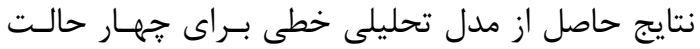
استفادهشه از ويزگگىهاى تصوير رادارى در جدول (9)،

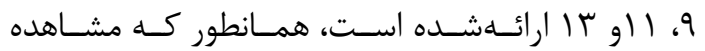

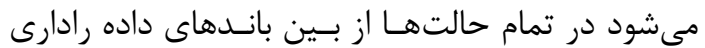

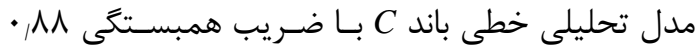
رطوبت خاى را تخمين زده است كه اين نشان مى دهد

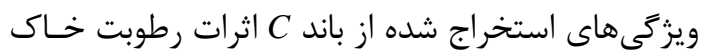
را با دقت بيشترى روى تصـوير رادار نشـان مسى دهـد.

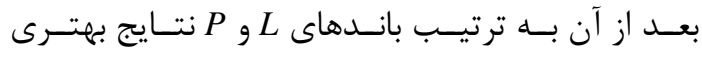

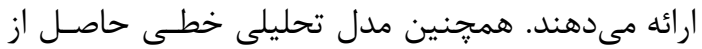
ويززَ نتـايج رضـايتبخـش بهتــرى نسـب بــه سـاير روشهـا

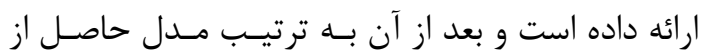
تمام ويزگى ها ، ويزگى هاى انتخابشده توسط الخوريتم

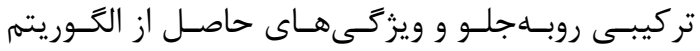
ترتيبى رو به عقب نتـايج مناسـبـتـرى بـراى محاسـبه

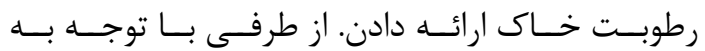

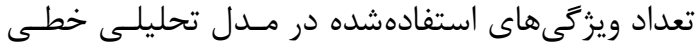

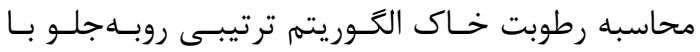
در نظر گرفتن 9 ويزگ

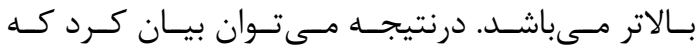

\section{مراجع}

Remote Sens., vol. 53, no. 2, pp. 645-658, Feb. 2015.

[2] L. Wang and J. J. Qu, "Satellite remote sensing applications for surface soil moisture monitoring: A review," Front. 
Earth Sci. China, vol. 3, no. 2, pp. 237-247, Jun. 2009

[3] P. S. Narvekar, D. Entekhabi, S. B. Kim, and E. G. Njoku, "Soil Moisture Retrieval Using L-Band Radar Observations," IEEE Trans. Geosci. Remote Sens., vol. 53, no. 6, pp. 3492-3506, Jun. 2015.

[4] Y. Oh, K. Sarabandi, and F. T. Ulaby, “An empirical model and an inversion technique for radar scattering from bare soil surfaces," IEEE Trans. Geosci. Remote Sens., vol. 30, no. 2, pp. 370-381, Mar. 1992.

[5] Attem; E.P.W; Ulaby; F.T, “ Vegetation modelled as a water cloud,", 1978, pp. 357364.

[6] M. Hosseini and M. r. Saradjian, "Soil moisture estimation based on integration of optical and SAR images," Can. J. Remote Sens., vol. 37, no. 1, pp. 112-121, Feb. 2011.

[7] M. Sarti and L. Mascolo, "An investigation of different polarimetric decomposition techniques for soil moisture estimation," in 2012 Tyrrhenian Workshop on Advances in Radar and Remote Sensing (TyWRRS), 2012, pp. 209-213.

[8] Lian He, Rocco Panciera, Member, IEEE, Mihai A. Tanase, Member, IEEE, Jeffrey P. Walker, Member, IEEE, and Qiming Qin. Soil Moisture Retrieval in Agricultural Fields Using Adaptive Model-Based Polarimetric Decomposition of SAR Data. 2016

[9] M. Moradizadeh and M. R. Saradjian, "The effect of roughness in simultaneously retrieval of land surface parameters," Phys. Chem. Earth, vol. 94, pp. 127-135, Aug. 2016.

[10]E. Khedri, M. Hasanlou, and A. Tabatabaeenejad, "Semi-analytical soil moisture retrieval using PolSAR imagery," in 2017 IEEE International Geoscience and Remote Sensing Symposium (IGARSS), 2017, pp. 4897-4900.

[11]Y. Maghsoudi, M.J. Collins, and D.G.Leckie, -Radarsat-2 polarimetric SAR data for Boreal forest classification using SVM and a wrapper feature selector, IEEE J. Selected Topics in Appl. Earth Observ. Remote Sens., vol. 6, no. 3, pp. 1531-1538, 2013.

[12]Z. Qi, A. G. Yeh, X. Li, and Z. Lin, -A novel algorithm for land use and land cover classification using RADARSAT-2 polarimetric SAR data, Remote Sens. Environ., vol. 118, pp. 21 - 39, 2012

[13][A. Haddadi, M.R. Sahebi, and A. Mansourian, -Polarimetric SAR feature selection using a genetic algorithm, Canadian J. Remote Sens., vol. 37, no. 1, pp. 27 - 36, 2011.

[14] M. Salehi, M.R. Sahebi, and Y. Maghsoudi, - Improving the accuracy of urban land cover classification using Radarsat-2 POLSAR data, || IEEE J. Selected Topics in Appl. Earth Observ. Remote Sens., vol. 7, no. 4, pp. 1394 - 1401, 2014.

[15] K. Z. Mao, “Orthogonal forward selection and backward elimination algorithms for feature subset selection," IEEE Trans. Syst. Man Cybern. Part B Cybern., vol. 34, no. 1, pp. 629-634, Feb. 2004.

[16] L. Guo, D. Rivero, J. Dorado, C. R. Munteanu, and A. Pazos, "Automatic feature extraction using genetic programming: An application to epileptic EEG ردبندى,", Expert Syst. Appl., vol. 38, no. 8, pp. 10425-10436, Aug. 2011.

[17] S.R. Cloude and E. Pottier, - A review of target decomposition theorems in radar polarimetry, || IEEE Trans. Geosci. Remote Sens., vol. 34, pp. 498 - 518, Mar. 1996.

[18]A. Freeman and S. Durden, - A threecomponent scattering model to describe polarimetric SAR data, \| in Proceedings SPIE Conference on Radar Polarimetry, Vol. 1748, pp. 213 - 225, San Diego, CA, July 1992.

[19]JONG-SEN LEE, ERIC POTTIER, "Polarimetric Radar Imaging: From Basics 
to Applications," 1stedition, February2009, pp 422،ISBN: 978-142005492

[20]Q. Vanhellemont and K. Ruddick, “Turbid wakes associated with offshore wind turbines observed with Landsat 8," Remote Sensing of Environment, vol. 145, pp. 105115, Apr. 2014.

[21]L. Zhuo, and J. Zheng, "A Genetic Algorithm Based Wrapper Feature Selection Method for Classification of Hyperspectral Image Using Support Vector Machine", The International Archives of the Photogrammetry, Remote Sensing and Spatial Information Sciences, 397-402, 2008.

[22]C.-L. Huang, and C.-J. Wang, "A GA-based feature selection and parameter optimization for support vector machines", Expert Systems with Application, 231-240, 2006.

[23][23] "Sequential Feature Selectormlxtend."[Online]. Available: http://rasbt.github.io /mlxtend/user_guide/feature_selection/Seque ntialFeatureSelector/. [Accessed: 20-Feb2017].

[24] Allen, P.B., and Naney, J.W, “ hydrology of the little washita river watershed oklahoma: data and analyses," USDA, ARS-90, P.P. 74, Washington, DC. 1991.

[25] "SMEX03 Data | National Snow and Ice DataCenter." [Online]. Available: http://nsidc.org/data/amsr_validation/soil_m oisture/smex03/index.html. [Accessed: 03Jan-2017].

[26]E. Khedri, M. Hasanlou, and A. Tabatabaeenejad, "Estimating Soil Moisture Using PolSAR Data: A Machine Learning Approach," in ISPRS - International Archives of the Photogrammetry, Remote Sensing and Spatial Information Sciences, 2017, vol. XLII-4-W4, pp. 133-137. 


\title{
Soil Moisture Linear Modeling by Using Decomposition and Selection of Fully Polarized SAR Features
}

\author{
Esmaeil Khedri ${ }^{1}$, Mahdi Hasanlou *2 \\ 1- Ms.c student of remote sensing in School of Surveying and Geospatial Engineering, College of Engineering, University of Tehran \\ 2- Assistant professor in School of Surveying and Geospatial Engineering, College of Engineering, University of Tehran
}

\begin{abstract}
Soil moisture is a key variable in the hydrologic process, which is affected by the exchange of water and energy on the Earth's surface. Precise estimation of spatial and temporal variations of soil moisture is crucial for environmental studies. The Polarimetric SAR (PolSAR) images are a convenient tool for this purpose. These images also guarantee both broad coverage and suitable spatial resolution. In this study, a linear analytical model has been suggested for estimating soil moisture. This model uses data gathered by the AIRSAR sensor in 2003 in C, L, and P bands. For this purpose, with incorporation of a genetic algorithm (GA), sequential forward selection (SFS), and sequential backward selection (SBS), we examine and select appropriate features best fitted for soil moisture modeling. Also in this estimation, soil moisture measurements were compared to in-situ data. The results showed that the proposed method (linear analysis model) had a good efficiency by using GA feature selection compare to both SFS and SBS feature selection. Regarding statistical parameters for proposed method, R2 model is higher than \%80 and RMSE is less than 0.027 for P, L, and C bands, which in comparison with other algorithms, the R2 model estimates soil moisture more accurately. Also, the best bands to estimate soil moisture model using proposed model and incorporated PolSAR features is the $\mathrm{C}$ band.
\end{abstract}

Key words: Linear analytical model, Soil moisture, GA, SFS, SBS.

Correspondence Address: School of Surveying and Geospatial Engineering, College of Engineering, University of Tehran, Tehran, Iran. Tel: +98 2161114525

Email: hasanlou@ut.ac.ir 